\title{
Jo eldre far, desto større morkake
}

\author{
Fars alder er én av flere faktorer \\ som har betydning for morkakens \\ størrelse.
}

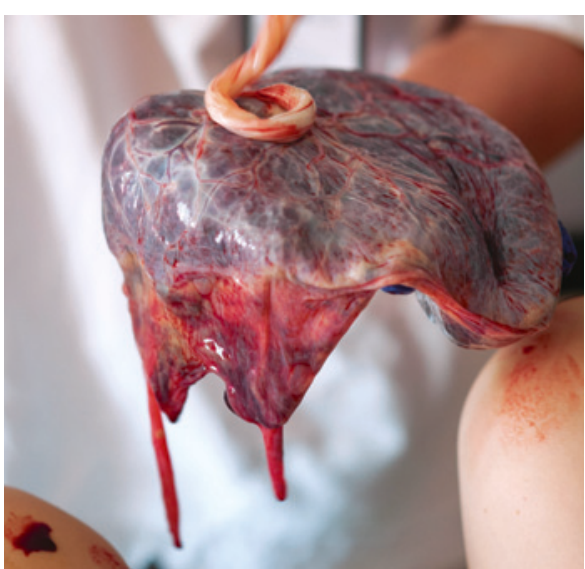

Illustrasjonsfoto Samfoto/NTB scanpix
Både svært små og svært store morkaker er knyttet til uheldig svangerskapsutfall. Vi har tidligere vist at mors alder er knyttet til størrelsen på morkaken (1). I en studie vi nylig har publisert i Human Reproduction fant vi at også fars alder er knyttet til morkakens vekt (2). Studien omfattet alle ettbarnsfødsler i Norge i perioden 1999-2009, totalt 590 835. Data er hentet fra Medisinsk fødselsregister.

Morkaken veide gjennomsnittlig $22 \mathrm{~g}$ mer i svangerskap der far var over 50 år enn i svangerskap der far var 20-24 år. Etter at man justerte for andre faktorer som man vet gir økt risiko for stor morkake, slik som mors alder, svangerskapsforgiftning og høy fødselsvekt, veide morkaken $14 \mathrm{~g}$ mer i svangerskap med fedre over 50 år enn der far tilhørte aldersgruppen 20-24 år. Der far var over 50 år, var morkaken også relativt stor i forhold til barnets størrelse.

Bak disse funnene kan det være flere årsaker, bl.a. endret evne til epigenetisk regulering i sædceller hos eldre menn. En annen årsak kan være forsterket seleksjon hvis faren er gammel - bare svangerskap med optimal morkakefunksjon når frem til fødsel. Funnene kan bidra til å forstå fars betydning for morkakevekst og dermed regulering av svangerskapet.

\section{Ellen Marie Strøm-Roum}

ellenmstrom@yahoo.no

Anne Eskild

Kvinneklinikken

Akershus universitetssykehus

\section{Litteratur}

1. Haavaldsen C, Samuelsen SO, Eskild A. The association of maternal age with placental weight: a population-based study of 536,954 pregnancies. BJOG 2011; 118: 1470-6.

2. Strøm-Roum EM, Haavaldsen C, Tanbo TG et al. Paternal age, placental weight and placental to birthweight ratio: a population-based study of 590835 pregnancies. Hum Reprod 2013. E-publisert 19.7

\section{Kateterimplantert aortaklaff er aktuelt også hos de aller eldste}

\author{
A implantere aortaklaffer via kateter er trygg og effektiv behandling \\ ved alvorlig aortastenose også hos dem over 90 år.
}

Aortastenose hos pasienter over 90 år behandles vanligvis konservativt. I en nylig publisert pasientserie fra Sveits ble 23 pasienter over 90 år med alvorlig aortastenose operert med transkateteraortaventilimplantasjon (TAVI) (1). Metoden går ut på at en mekanisk aortaventil settes inn gjennom et kateter som føres via en stor arterie (oftest i lysken) til hjertet. Ingen av pasientene hadde uttalt komorbiditet eller høy risiko for snarlig død.

Første postoperative måned døde to pasienter, én fikk hjerneslag og tre fikk livstruende blødning. Implantasjonen var vellykket hos 17 pasienter, og etter ett år var 17 fortsatt i live. Forfatterne konkluderer med at pasienter der symptomgivende aortastenose er hovedårsaken til redusert funksjonsnivå og livskvalitet, bør vurderes for aortaklaffimplantasjon, uavhengig av alder.

- Denne studien bekrefter at dette er en nyttig behandlingsprosedyre ved aortastenose hos selekterte eldre pasienter, sier thoraxkirurgene Gry Dahle og Kjell Arne Rein ved Oslo universitetssykehus, Rikshospitalet. - Hos svært gamle mennesker med flere tilleggssykdommer vil risikoen for komplikasjoner under og etter operasjonen være høy. Operasjonen gir først og fremst bedre livskvalitet, levetiden blir ikke vesentlig forlenget. I denne studien benyttet man transfemoral tilgang hos de fleste pasientene, noe som gjenspeiler fravær av uttalt aterosklerotisk karsykdom, sier de.

- Forekomsten av komplikasjoner som hjerneslag, lekkasjer og ledningsforstyrrelser var i denne studien av samme omfang som i tilsvarende undersøkelser. Vi støtter forfatternes konklusjon om at transkateteraortaventilimplantasjon bør vurderes hos eldre med alvorlig aortastenose når det ikke foreligger klare kontraindikasjoner, sier Dahle og Rein.

\section{Matilde Risopatron Berg}

matilde.risopatron.berg@legeforeningen.no Tidsskriftet

\footnotetext{
Litteratur

1. Noble S, Frangos E, Samaras N et al. Transcatheter aortic valve implantation in nonagenarians: effective and safe. Eur J Intern Med 2013. E-publisert 7.8 .
}

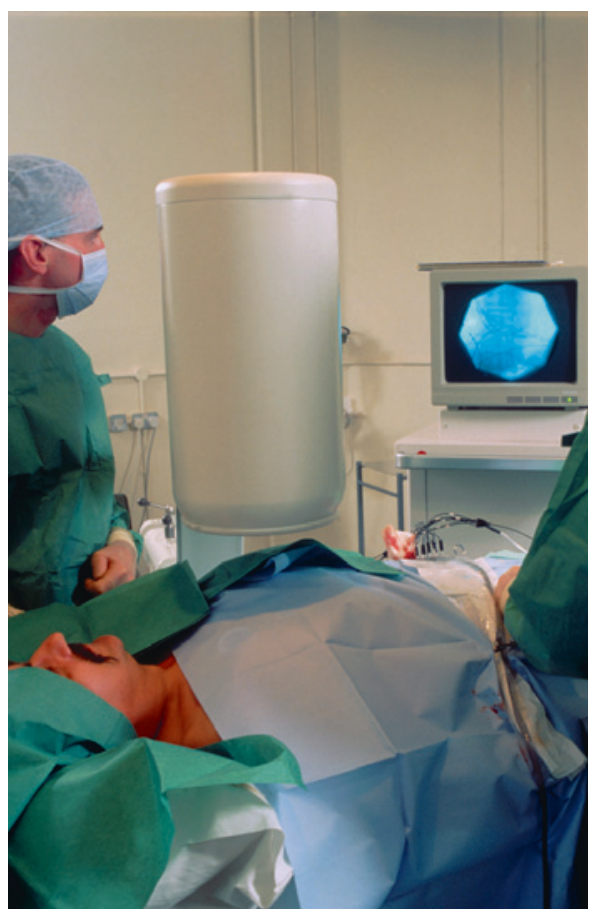

Illustrasjonsfoto NTB scanpix 